\title{
Phytochemical Screening, Tyrosinase Inhibitory Effects and Kinetics of Cam Wood Dye Extracts
}

\author{
David Morakinyo Sanni", Oluwasegun Victor Omotoyinbo \\ Department of Biochemistry, Federal University of Technology, Akure, Ondo State, Nigeria
}

Email address:

moraksanni@yahoo.co.uk (D. M. Sanni)

${ }^{*}$ Corresponding author

\section{To cite this article:}

Sanni David Morakinyo, Omotoyinbo Oluwasegun Victor. Phytochemical Screening, Tyrosinase Inhibitory Effects and Kinetics of Cam Wood Dye Extracts. Advances in Biochemistry. Vol. 4, No. 2, 2016, pp. 16-20. doi: 10.11648/j.ab.20160402.12

Received: February 5, 2016; Accepted: February 18, 2016; Published: April 28, 2016

\begin{abstract}
Tyrosinase is a key enzyme in melanin biosynthesis, as it catalyzes the oxidation of o-diphenols to o-quinones. Cam wood dye was extracted using methanol, acetone and dichloromethane; while extracts obtained were screened for Phytochemicals as well as their tyrosinase inhibitory effects and kinetic studies. Phytochemical screening of the three extracts showed the presence of total phlobatanins in all extracts except methanolic which had minute presence. Cardiac glycosides and flavonoids were also observed in the dichloromethane extracts and methanolic extract respectively. The methanolic extracts had best enzyme inhibition (84.1\%) at highest concentration considered of $400 \mu \mathrm{g} / \mathrm{ml}$ as compared to the dichloromethane and acetone extracts with peak values of 58.5 and $51.5 \%$ respectively. The enzyme kinetics analysis of substrate showed same inhibition type for three extracts which was non-competitive and its mechanism irreversible. The Michealis-Mentens constants for the three extracts were determined to be $0.344,0.355$ and $0.214 \mathrm{mM}$, for acetone, dichloromethane and methanolic extracts respectively while the values of $\mathrm{V}_{\max } / \mathrm{K}_{\mathrm{m}}$ shows inhibiting extracts followed the order: methanol extract $>$ acetone extract $>$ dichloromethame extract. The result therefore showed that methanolic extracts of Cam wood dye was the most effective in tyrosinase inhibition.
\end{abstract}

Keywords: Cam Wood Dye, Tyrosinase, Inhibition, Phytochemicals

\section{Introduction}

Plants have been identified and used throughout human history. Plants have the ability to synthesize a wide variety of chemical compounds as part of their normal metabolic activities, these compounds are used to perform important biological functions, and to defend against attack from predators such as insects, fungi and herbivorous mammals [1]. Phytochemicals are large group of plant derived compounds hypothesize to be responsible for much of the disease protection conferred from diets. These phytochemicals are divided into primary metabolites such as sugars and fats, which are found in all plants; and secondary metabolites; compounds which are found in a smaller range of plants, serving a more specific function [2].

Tyrosinase (EC 1.14.18.1) is a copper-containing enzyme present in plant and animal tissues that catalyzes the production of melanin and other pigments from tyrosine by oxidation [3, 4]. Tyrosinase is found inside melanosomes it is encoded by the TYR gene [5]. It is mainly involved in two distinct reactions of melanin synthesis (melanogenesis); firstly, the hydroxylation of a monophenol and secondly, the conversion of an o-diphenol to the corresponding o-quinone. O-Quinone then undergoes several reactions to eventually form melanin [6]. Hence, the pigmentation, spots, freckles, found on the skin are generally considered to be caused as a result of the melanin production enhanced by the activated melanocyte present in the skin due to the stimulation from skin exposure to ultraviolet ray, hormonal imbalance and genetic factors.

Traditional herbal medicines provide an interesting, largely unexplored source for development of potential new drugs. The potential use of traditional herbal medicines for development of new skin-care cosmetics has been emphasized recently [7]. It is of great interest to know whether preparations used cosmetically in folk medicines have activities that might be useful in modern formulations. 
The aim of this study is to screen for the tyrosinase inhibitory activity of the methanol, acetone and dichloromethane extracts of Cam wood dye. Commercially available tyrosinase inhibitors are mainly chemical and fungal derived skin-lightening agents that have been proven to have chronic mutagenic and cytotoxic effects on humans [8]. Therefore evaluation and identification of tyrosinase inhibitors with potent activities and lower side effects from natural products would be the safest alternative possible.

\section{Materials and Method}

\subsection{Plant Collection and Extraction}

The Cam wood dye was gotten from Idanre town, Ondo state alongside other parts of the tree plant for authentication. Thereafter $5 \mathrm{~g}$ of sample was dissolved in $25 \mathrm{ml}$ of the three solvents considered; that is methanol $(\mathrm{MeOH})$, acetone and dichloromethane (DCM). They were incubated at $50^{\circ} \mathrm{C}$ with continuous agitation for 5 hours in a shaking-water bath. The solvent were removed and replaced with an equal volume of solvent and the procedure repeated two more times. The extracts obtained were filtered using whatmann filter paper while the clear filtrate was placed in fume cupboard for solvents to evaporate and in obtaining dry extracts.

\subsection{Phytochemical Screening}

Qualitative analysis of the crude extracts was carried out as described previously $[9,10,11,12,13,14]$ to identify the presence of secondary metabolites (alkaloids, anthraquinones, flavonoids, tannins, saponins, phenol, glycosides, cardiac glycosides and steroids). The detail procedures involved in the phytochemical screening are as described by Ushie and Adamu [15].

\subsection{Tyrosinase Inhibition Assay}

Extracts/purified compounds were dissolved in dimethyl sulfoxide (DMSO) to a final concentration of $20 \mathrm{mg} / \mathrm{ml}$. This extract stock solution was then diluted to $600 \mu \mathrm{g} / \mathrm{ml}$ in 50 $\mathrm{mM}$ potassium phosphate buffer $(\mathrm{pH} 6.5)$. Kojic acid were used as positive controls. $700 \mu$ of each sample solution of

different concentrations $(3.1-400 \mu \mathrm{g} / \mathrm{ml})$ were combined with $300 \mu \mathrm{l}$ of tyrosinase (50 Units $/ \mathrm{ml}$ in phosphate buffer, $\mathrm{pH}$ 6.5) in triplicate inside test-tubes. After incubation at room temperature for $5 \mathrm{~min}, 1.1 \mathrm{ml}$ of substrate $(12 \mathrm{mM} \mathrm{L}$ DOPA) were added to each well. Final concentrations of the extract were $3.1,6.2,12.5,25,50,100,200$ and $400 \mu \mathrm{g} / \mathrm{ml}$. Final concentrations of pure compound and positive control were $1.5,3.1,6.2,12.5,25,50,100$ and $200 \mu \mathrm{g} / \mathrm{ml}$. Testtubes were incubated for $30 \mathrm{~min}$ at room temperature, after which optical densities of the test mixtures were then determined at $492 \mathrm{~nm}$ using visible spectrophotometer.

The percentage tyrosinase inhibition was calculated as follows:

$$
\% \text { Inhibition }=\left[1-\frac{(A 3-A 4)}{(A 1-A 2)}\right] * 100
$$

A1 $=$ Acontrol i.e. Abs of test with L-DOPA but no sample

$\mathrm{A} 2=$ Blank i.e. Abs of test with no sample or L-DOPA

A3 = Asample i.e. Abs of test with sample and L-DOPA

$\mathrm{A} 4=\mathrm{Abs}$ before adding substrate i.e. L-DOPA

The extent of inhibition by the addition of the sample was expressed as the percentage inhibition and the initial velocity was plotted against substrate concentration.

The inhibition mechanism of different concentrations (25 $\mu \mathrm{g} / \mathrm{ml}, 50 \mu \mathrm{g} / \mathrm{ml}, 100 \mu \mathrm{g} / \mathrm{ml}, 200 \mu \mathrm{g} / \mathrm{ml}$ and $400 \mu \mathrm{g} / \mathrm{ml})$ plant extracts on enzyme activity to plot their activity against effectors concentration. $0.1 \mathrm{ml}$ of the different concentration of extracts were mixed with $2.8 \mathrm{ml}$ of reaction solution (consisting of $12 \mathrm{mM}$ L-DOPA in $50 \mathrm{mM}$ sodium phosphate buffer, $\mathrm{pH}$ 6.5). Then, a portion of $100 \mu \mathrm{l}$ of enzyme solution was added into this mixture and we determined the residual activity at $30^{\circ} \mathrm{C}$. In the activity assay system, substrates concentration $(2.5,5.0,7.5,10.0,12.0) \mathrm{mM}$ was changed to determine the enzymatic oxidation initial velocity. According to Michaelis-Menten kinetics, plots of Lineweaver-Burk were made to estimate the kinetic parameters $\left(\mathrm{K}_{\mathrm{m}}\right.$ and $\left.\mathrm{V}_{\max }\right)$.

\section{Results and Discussion}

Table 1. Phytochemical screening of Cam wood dye extracts

\begin{tabular}{llllllll}
\hline TEST SAMPLES & SAPONINS & TANNINS & FLAVONOID & CARDIAC GLYCOSIDES & ALKALOID & PHLOBATANINS \\
\hline BA & -- & -- & -- & -- & -- & ++ \\
BB & -- & -- & -- & ++ & -- & ++ \\
BC & -- & -- & ++ & -- & -- & + & + \\
\hline
\end{tabular}

$--=$ Absent $(++)=$ presence $(+)=$ slightly present

$\mathrm{BA}=$ Acetone extract, $\mathrm{BB}=\mathrm{DCM}$ extract, $\mathrm{BC}=\mathrm{MeOH}$ extract

Phytochemical screening of acetone extract of Cam wood dye as observed from Table 1 showed the presence of phlobatannins, while the dichloromethane extract has phlobatannins and cardiac glycosides. This Cardiac glycosides present in the dichloromethane extract of Cam wood dye might make the plant useful therapeutically primarily in the treatment of cardiac failure. The methanol extract contains total flavonoids and a minute presence of phlobatannins, as compared with some other plants like strawberries, apples, onions, almonds, etc. that contains flavonoids [16]. Some of the phytochemicals that are present in this dye may have compounds similar to some already 
known tyrosinase inhibitors as previously [17]; examples include hydroquinone which contains flavonoids and arbutin which also are made up of glucosides. Hence this can contribute to the dyes extract tyrosinase inhibitory properties.

Under the conditions employed in this present investigation, the oxidation reaction of L-DOPA by mushroom tyrosinase followed Michaelis-Menten kinetics.

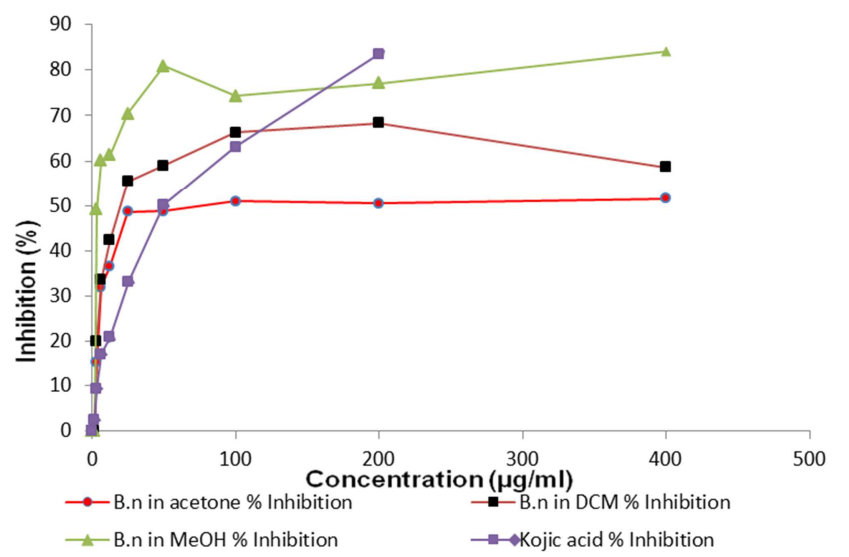

Figure 1. Tyrosinase inhibition of Cam wood dye extracted by three solvents; Acetone, $\mathrm{DCM}$ and $\mathrm{MeOH}$.

The results obtained for inhibition of tyrosinase indicates that the three plant extract of Cam wood has inhibitory effect above $50 \%$ at different concentrations. Michealis Menten plot from Figure 1 indicates that acetone extract had 50\% inhibition $(50.91 \%)$ of tyrosinase at concentration of 100 $\mu \mathrm{g} / \mathrm{ml}$ of extract, the dichloromethane extract had its own $50 \%$ inhibition with a value of $(55.46 \%)$ at $25 \mu \mathrm{g} / \mathrm{ml}$ which is higher than that of acetone extract while the methanol extract has its own $50 \%$ tyrosinase inhibition $(60.05 \%)$ at a concentration of $6.2 \mu \mathrm{g} / \mathrm{ml}$. The methanolic extract therefore showed the best inhibition of mushroom tyrosinase. This result observed confirms similar findings on tyrosinase inhibition of some spices: Black pepper $58.20 \%$, Caraway $58.3 \%$, and Turmeric $88.56 \%$, which showed more than $50 \%$ inhibition.

Tyrosinase inhibitory activities of the acetonic, dichloromethane and methanolic extracts from Cam wood dye increased with increasing concentration. At 3.1 to 400 $\mu \mathrm{g} / \mathrm{ml}$ the tyrosinase inhibition of acetone, dichloromethane and methanolic extract ranged from 15.49 to $51.52,19.88$ to $58.62 \%$ and 49.13 to $84.1 \%$, respectively. These results indicate that methanolic extract showed good activities, while acetone and dichloromethane extracts showed moderate activities at the concentrations tested. However, at 1.5 to $200 \mu \mathrm{g} / \mathrm{ml}$ kojic acid showed excellent tyrosinase inhibitory activity of 2.53 to $83.48 \%$. The inhibition of tyrosinase might depend on the hydroxyl groups of the phenolic compounds of the mushroom tyrosinase that could form a hydrogen bond to the active site of the enzyme, leading to a lower enzymatic activity. Baek et al., [18] earlier suggested that some tyrosinase inhibitors acts through hydroxyl group that bind to the active site on tyrosinase, resulting to steric hindrance or change in conformation.
Kojic acid at the concentration of $200 \mu \mathrm{g} / \mathrm{ml}$ has its highest anti-tyrosinase activity (83.48\%) when compared with the three extracts of Cam wood dye, however acetone, dichloromethane and methanol extract has $50 \%, 68 \%$ and $77 \%$ respectively at thesame inhibitor concentration. The methanolic extract has the highest inhibitory activity at $200 \mu \mathrm{g} / \mathrm{ml}$ of $77.12 \%$, however, this makes it the closest to the inhibitory activity of kojic acid (83.43\%).

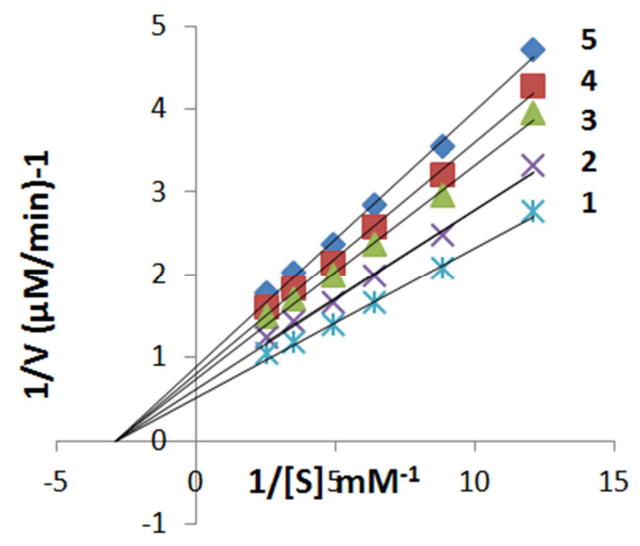

(a)

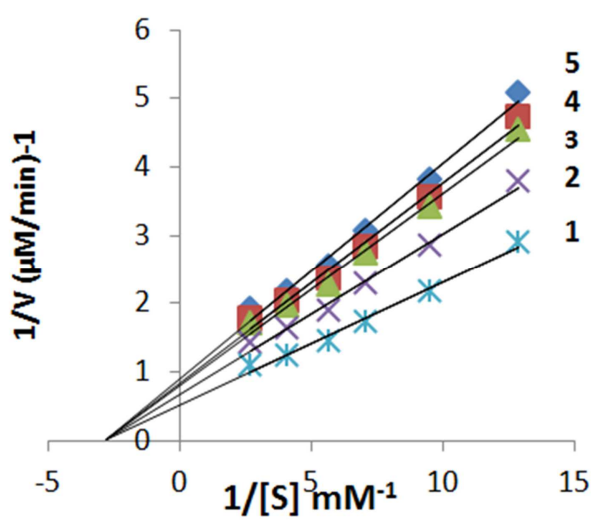

(b)

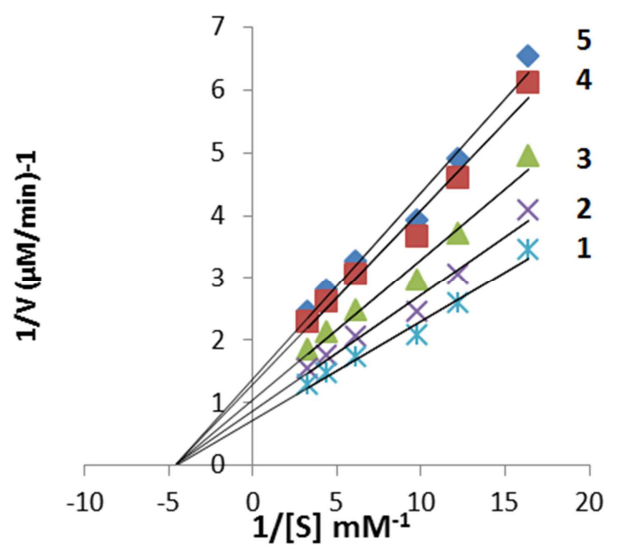

(c)

Figure 2. Lineweaver-Burk for the inhibitionn of Cam wood dye (a) acetone extract (b) dichloromethane extract (c) methanol extract on the oxidation of L-DOPA by mushroom tyrosinase with concentration of extract shown in curves $1-5$ being $2.5 \mathrm{mM}, 5 \mathrm{mM}, 7.5 \mathrm{mM}, 10 \mathrm{mM}$ and $12 \mathrm{mM}$. 
Cam wood dye extract showed Noncompetitive Inhibitory type on the Diphenolase Activity as shown in figure 2 for acetone (a), dichloromethane (b) and methanol (c) extract respectively; the Lineweaver-Burk plots of $1 / v$ versus $1 /[\mathrm{S}]$ give a family of lines with different slope and intersect one another on the $X$-axis, indicating that all the Cam wood dye extract were a noncompetitive inhibitor of diphenolase [19]. This inhibitor binds to another site on the enzyme and inactivates the enzyme molecule. This effectively reduces the [E]tot available for catalysis. Since Vmax is proportional to [E]tot, Vmax is reduced. While the remaining active enzyme molecules are unaltered, $\mathrm{Km}$ is unchanged.

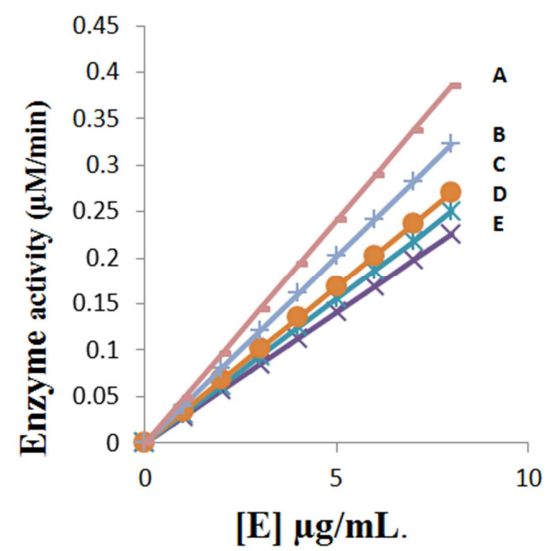

(a)

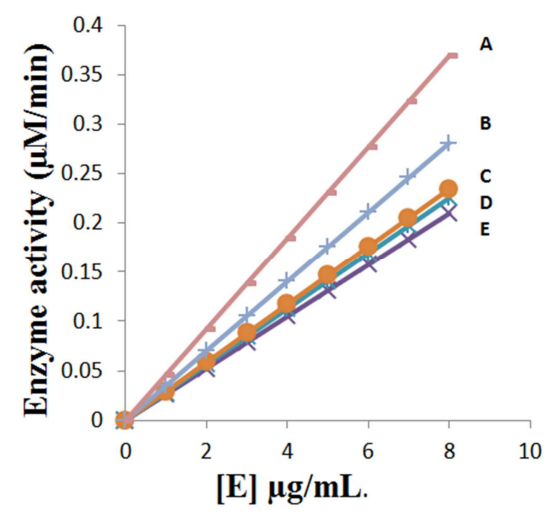

(b)

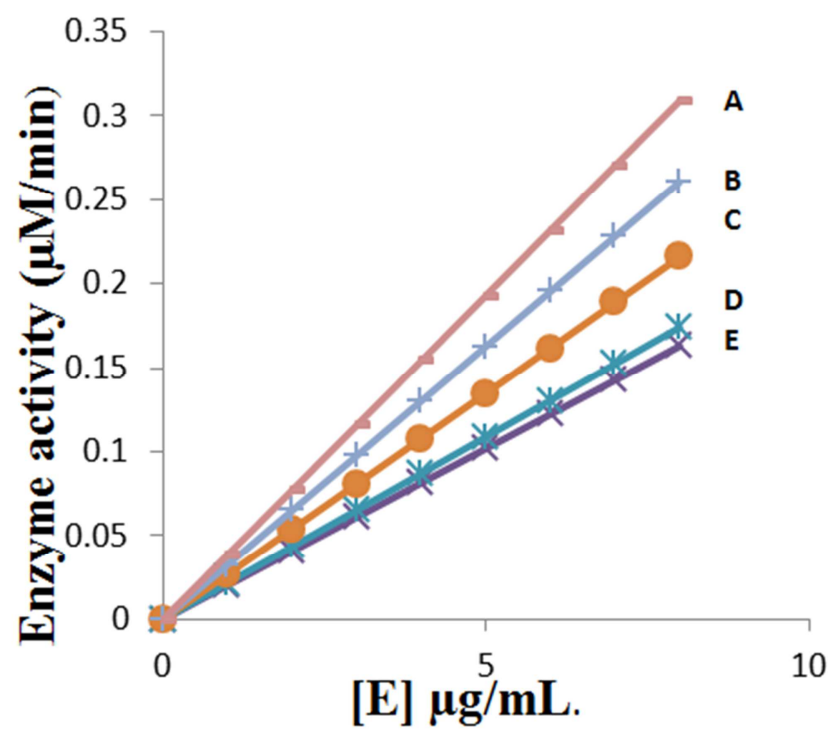

(c)

Figure 3. Determination of inhibitory mechanism of Cam wood dye (a) acetone extract, (b) dichloromethane extract, (c) methanol extract, on mushroom tyrosinase. Where $A=400 \mu \mathrm{g} / \mathrm{ml}, B=200 \mu \mathrm{g} / \mathrm{ml}, C=100 \mu \mathrm{g} / \mathrm{ml}$, $D=50 \mu \mathrm{g} / \mathrm{ml}$ and $E=25 \mu \mathrm{g} / \mathrm{ml}$ of extract.

Cam wood dye extract was also used as an effector on the activity of mushroom tyrosinase for the oxidation of LDOPA as seen in figure 3 . The plots of the remaining enzyme activity versus the concentrations of enzyme in the presence of different concentrations of Cam wood dye extracts gave a family of straight lines, which all passed through the origin, indicating that that inhibition of these extracts on the diphenolase had the slope of the lines markedly increased with increasing concentration of all the extracts hence depicting an irreversible reaction course. The presence of Cam wood dye extract did not bring down the amount of the efficient enzyme, but just resulted in the descending of the activity of the enzyme [20].

Table 2. The kinetic parameters of mushroom tyrosinase for the oxidation of L-DOPA.

\begin{tabular}{llll}
\hline Substrates & $\mathbf{K m}(\mathbf{m M})$ & $\mathbf{V m a x}(\boldsymbol{\mu M} / \mathbf{m i n})$ & $\mathbf{V m a x} / \mathbf{K m}\left(\mathbf{1 0} \mathbf{m i n}^{-\mathbf{1}}\right)$ \\
\hline acetone extract & 0.344 & $1.436 \pm 0.316$ & $4.17 \pm 0.918$ \\
dichloromethane extract & 0.355 & $1.413 \pm 0.347$ & $3.99 \pm 0.978$ \\
methanolic extract & 0.214 & $0.993 \pm 0.269$ & $4.64 \pm 1.257$ \\
\hline
\end{tabular}

The order of $\mathrm{km}$ values for the three extracts studied were as follow; dichloromethane extract $>$ acetone extract $>$ methanolic extract, and the minimum value for dichloromethane extract was $0.335 \mathrm{mM}$. In addition Vmax values indicate that acetone and methanol are catalyse by enzymes at maximum and minimum rates $(1.436 \pm 0.316$ and $0.993 \pm 0.269 \mu \mathrm{M} / \mathrm{min})$ respectively. The calculated values of Vmax $/ \mathrm{Km}$ show the specificity of substrates towards mushroom tyrosinase. As seen in table 2 the order of $\mathrm{Vmax} / \mathrm{Km}$ values for the four substrates was as follows: methanol extract $>$ acetone extract $>$ dichloromethane extracts.

\section{Conclusion}

The findings in this study provides scientific basis to promote value-adding of Cam wood dye for pharmaceutical 
and cosmetic purposes, because of the strong anti-tyrosinase activities of its methanolic extracts.

\section{References}

[1] Lichterman B. L. (2004). "Aspirin: The Story of a Wonder Drug". British Medical Journal, 329 (74-79): 1408.

[2] Tapsell L. C., Hemphill I., Cobiac L., Patch C. S., Sullivan D. R., Fenech M., Roodenrys S., Keogh J. B., Clifton P. M., Williams P. G., Fazio V. A., Inge K. E. (2006). "Health benefits of herbs and spices: the past the present, the future." Med. J. Aust. 185(4 Supply): S4-24.

[3] Zawistowski J., Biliaderis C. G., Eskin N. A. M. (1991). Polyphenol oxidase. In: Oxidative Enzymes in Foods, Substrate Elsevier, London, 217-273.

[4] Whitaker J. R. (1995). Polyphenol oxidase. In: Food Enzymes, Structure and Mechanism. Chapman and Hall, New York, 271-307.

[5] Barton D. E., Kwon B. S., Francke U. (1988). "Human tyrosinase gene, mapped to chromosome, defines second region of homology with mouse chromosome 7".Genomics 3 (1): 17-24.

[6] Kumar C. M., Sathisha U. V., Dharmesh S., Rao A.G., Singh S.A. (2011). "Interaction of sesamol (3, 4methylenedioxyphenol) with tyrosinase and its effect on melanin synthesis". Biochimie 93 (3): 562-9.

[7] Seiberg M., Paine C., Sharlow E., Andrade-Gordon P., Costanzo M., Eisinger M., Shapiro S.S. (2000). Inhibition of Melanosome Transfer Results in Skin Lightening. J. Investigative Dermatology 115, 162-167.

[8] Petit L., Piérard G. E. (2003). Skin-lightening products revisited. International Journal of Cosmetic Science, 25: 169181.

[9] Brain K. R., Turner T. D. (1975). The practical evaluation of phytopharmaceuticals, Wright-science technical, Bristol Britain, 56-64.
[10] Sofowora A. O. (1993). Medicinal Plants and Traditional Medicine in Africa. University of Ife Press 2nd Edition, 320.

[11] Edeoga H. O., Okwu D. E., Mbaebie B. O. (2005). Phytochemical constituents of some Nigerian medical plants. African J. Biotechnology, 4: 685-688.

[12] Trease G. E., Evans W. C. (2000). Pharmacognosy.14th Edition Harcourt Publishers Limited London.

[13] Harbone N. V. (1994). Phytochemical methods: A guide to modern techniques of plant analysis, 2nd Edition, Chapman and Hall London., 425.

[14] Osuagwu G. G. E., Okwulehie I. C., Emenike J. O. (2007). Phytochemical and Mineral content of the leaves of four Nigerian Pterocarpus species. Int. J. Mol. Med. Adv. Sci, 3(1): $6-11$.

[15] Ushie O. A., Adamu H. M. (2010). Phytochemical Screening of Borreria verticillata leaves. Journal of Agriculture, Biotechnology and Ecology, 3(1): 108-117.

[16] Chun O. K., Chun S. J., Song W. O. (2007). Estimated dietary flavonoid intake and major food sources of US adults. J Nutr; $137: 1244-52$.

[17] Momtaz S. (2006). Anti-tyrosinase activity of eleven plants. Honours Thesis; Diseases: What's new? European Academy of Dermatology and Venereology JEADV, 17: 663-669.

[18] Baek S., Kim J., Kim D., Lee C., Kim J., Chung D. K., Lee C. (2008). Inhibitory effect of dalbergioidin isolated from the trunk of Lespedeza cyrtobotrya on melanin biosynthesis. J. Microbiol. Biotechnol, 18, 874-879.

[19] Huang Q., Zhu Y., Li H., Zhuang J., Zhang C., Zhou J., Li W., Chen Q. (2009). Inhibitory Effects of Methyl trans-Cinnamate on Mushroom Tyrosinase and its Antimicrobial Activities. J. Agric. Food Chem., DOI: 10.1021/jf8036227.

[20] Xie J. J., Song K. K., Qui L., He Q., Huang H., Chen Q. X. (2007). Inhibitory effect of substrate and analogues on enzyme activity and substrate specificities of mushroom tyrosinase. Food Chem., 103, 1075-1079. 